\title{
IMPLEMENTASI PELAPORAN KEUANGAN BERBASIS DIGITAL DI YAYASAN RADIYATAN MARDIYAH PRUMPUNG JAKARTA TIMUR
}

\author{
Jurica Lucyanda ${ }^{1^{*}}$, Tuti Widiastuti ${ }^{2}$, Berkah Iman Santoso ${ }^{3}$ \\ ${ }^{1}$ Program Studi Akuntansi, ${ }^{2}$ Program Studi IImu Komunikasi, Fakultas Ekonomi dan Ilmu Sosial, \\ ${ }^{3}$ Program Studi Informatika, Fakultas Teknik dan IImu Komputer, Universitas Bakrie, Indonesia \\ E-mail: jurica.lucyanda@bakrie.ac.id*, tuti.widiastuti@bakrie.ac.id, berkah.santoso@bakrie.ac.id
}

Received: August 2, 2021 / Revised: August 23, 2021 / Accepted: October 7, 2021

DOI: https://doi.org/10.36782/ijsr.v3i2.89

\begin{abstract}
ABSTRAK
Pengabdian ini bertujuan memberikan pelatihan terkait dengan pelaporan keuangan entitas berorientasi nonlaba (EBNL) kepada Yayasan Radiyatan Mardiyah (YRM) Prumpung Tengah Jakarta Timur berdasarkan Interpretasi Standar Akuntansi Keuangan (ISAK) 35 berbasis digital. Permasalahan yang dihadapi oleh Yayasan Radiyatan Mardiyah sebagai entitas berorientasi nonlaba (EBNL) adalah yayasan yang baru berdiri dan pembuatan laporan keuangan berdasarkan standar akuntansi yang telah dibuat oleh Ikatan Akuntan Indonesia (IAI) sesuai dengan kebutuhan masing-masing entitas. Keterbatasan pemahaman pengurus Yayasan terkait dengan komunikasi internal/eksternal dan pelaporan keuangan berdasarkan standar tertentu menjadi hal yang penting untuk difasilitasi dengan memberikan pelatihan komunikasi internal/eksternal untuk penguatan organisasi serta penyusunan laporan keuangan berdasarkan ISAK 35. Selain itu adanya tuntutan berkembangan teknologi yang pesat, menjadi fokus kegiatan pengabdian ini untuk memfasilitas pengurus yayasan dapat membuat laporan berbasis digital, sehingga laporan keuangan dapat dibuat dengan mudah. Metode kegiatan pelatihan dan sosialisasi dilaksanakan dengan sistem online karena kondisi pandemik Covid-19. Kegiatan pelatihan dilakukan dengan tahapan pre-test, pemaparan materi pelatihan, diskusi dan tanya jawab. Hasil pre-test menyimpulkan bahwa pengurus Yayasan memahami laporan keuangan sederhana namun tidak memahami ISAK 35. Pelatihan berfokus menjelaskan laporan keuangan berdasarkan ISAK 35. Kegiatan selanjutnya setelah pelatihan dilaksanakan kegiatan sosialisasi laporan keuangan yang berbasis web. Sosialisasi laporan keuangan berbasis digital berdasarkan ISAK 35 dilakukan untuk menjelaskan kepada pengurus khususnya bagian keuangan dan akuntansi agar paham bagaimana mencatat semua transaksi menggunakan sistem akuntansi berbasis web yang dibangun. Adanya keterbatasan waktu kegiatan maka kelanjutan kegiatan ini adalah melakukan pendampingan dalam bentuk monitoring dan evaluasi penerapan ISAK 35 di YRM.
\end{abstract}

Kata kunci: Entitas Berorientasi Nonlaba, Interpretasi Standar Akuntansi Keuangan, Komunikasi Internal dan Eksternal, Literasi Digital, Pelaporan Keuangan Berbasis Digital.

\section{ABSTRACT}

This service aims to provide training related to financial reporting of non-profit oriented entities (EBNL) to the Radiyatan Mardiyah Foundation (YRM), Prumpung Tengah, East Jakarta based on the digital-based Interpretation of Financial Accounting Standards (ISAK). The problems faced 
by the YRM as a non-profit oriented entity (EBNL) are the newly established foundation and the preparation of financial reports based on accounting standards that have been made by the Indonesian Institute of Accountants (IAI) according to the needs of each entity. The limited understanding of the Foundation's management related to internal/external communication and financial reporting based on certain standards is an important thing to be facilitated by providing internal/external communication training for organizational strengthening and preparation of financial reports based on ISAK 35. In addition, the demands for rapid technological development have become focus of this service activity is to facilitate foundation management to make digital-based reports, so that financial reports can be made easily. The method of training and socialization activities is carried out with an online system due to the Covid 19 pandemic conditions. Training activities are carried out with pre-test stages, presentation of training materials, discussions and questions and answers. The pre-test results concluded that the foundation management mostly understood the simple financial statements but did not understand ISAK 35. The training focuses on explaining financial statements based on SAK 35. Furthermore, after the training is carried out socialization of web-based financial statements. The socialization of digital-based financial reports based on ISAK 35 was carried out to explain to the management, especially the finance and accounting divisions so that they understand how to record all transactions using the system built. There is limited time of the service activity then the continuation of this activity is to conduct assistance in the form of monitoring and evaluations of implementation ISAK 35 in YRM.

Keywords: Digital-Based Financial Reporting, Digital Literacy, Internal and External Communication, Interpretation of Financial Accounting Standards, Non-Profit Oriented Entities.

\section{PENDAHULUAN}

Hidup bermasyarakat merupakan bagian kehidupan manusia sebagai makhluk sosial. Hidup bermasyarakat umumnya dalam bentuk bekerjasama dalam mengatur dan mengorganisasi kegiatannya untuk mencapai tujuan. Umumnya untuk memformalkan hidup bermasyarakat ini dibentuklah suatu entitas atau organisasi. Bentuk organisasi dikalangan masyarakat untuk kegiatan bermasyarakat untuk membantu secara sosial diantaranya adalah organisasi nonlaba (non-profit), yang sering pula disebut dengan entitas berorientasi nonlaba (EBNL). Organisasi nonlaba sebagai organisasi yang tidak berorientasi pada laba, tetapi berperan dalam membantu salah satu masalah utama yang sering dihadapi oleh negara-negara berkembang seperti Indonesia, yaitu kemiskinan. Sebagaimana halnya organisasi sosial, organisasi nonlaba seperti yayasan juga membutuhkan jasa akuntansi untuk membuat laporan keuangan sebagai bentuk pertanggungjawaban keuangan yayasan (Wahyuningsih dkk., 2018).

Praktek akuntansi pada lembaga nonlaba merupakan sesuatu yang jarang dilakukan dan kurang dipahami bagi karena keterbatasan pemahaman dan pengetahuan dalam penyusunan laporan keuangan.

Menurut Ikatan Akuntan Indonesia/IAI (2018), berdasarkan Pernyataan Standar Akuntansi Keuangan (PSAK) No. 1, laporan keuangan adalah catatan informasi keuangan 
suatu perusahaan pada suatu periode akuntansi yang dapat digunakan untuk menggambarkan kinerja perusahaan tersebut. Laporan keuangan merupakan hasil dari proses akuntansi yang dapat digunakan sebagai alat komunikasi antara data keuangan atau aktivitas suatu perusahaan dengan pihak yang berkepentingan dengan data atau aktivitas dari perusahaan. Meskipun EBNL tidak berorientasi terhadap laba, EBNL tetap memerlukan informasi akuntansi karena EBNL memiliki anggaran dan pengeluaranpengeluaran yang perlu dibayarkan untuk operasional entitas serta urusan keuangankeuangan lainnya, sehingga EBNL perlu membuat laporan keuangan yang berbeda dengan laporan keuangan entitas berorientasi laba (Ikatan Akuntansi Indonesia, 2018).

Dewan Standar Akuntansi Keuangan Ikatan Akuntan Indonesia (DSAK IAI) membuat PSAK 45 yang berlaku untuk EBNL. Namun karena adanya kebutuhan yang signifikan untuk ketidakjelasan yang dihadapi oleh EBNL maka IAI berusaha untuk menyelesaikan ketidakjelasan dan permasalahan yang terjadi dengan mengesahkan Intrepretasi Standar Akuntansi Keuangan (ISAK 35) tentang "Penyajian Laporan Keuangan Entitas Berorientasi Nonlaba" dan mencabut PSAK 45 tentang "Pelaporan Keuangan Entitas Nirlaba" pada tanggal 11 April 2019 yang berlaku efektif untuk periode tahun buku yang dimulai pada atau setelah tanggal 1 Januari 2020 (Ikatan Akuntansi Indonesia, 2018).
Permasalahan yang selama ini banyak dihadapi oleh EBNL adalah pembuatan laporan keuangan berdasarkan standar akuntansi yang telah dibuat oleh IAI sesuai dengan kebutuhan masing-masing entitas. Keterbatasan pemahaman pengurus yayasan terkait dengan bagaimana membuat laporan keuangan berdasarkan standar tertentu menjadi hal yang penting untuk difasilitasi dengan memberikan pelatihan penyusunan laporan keuangan untuk EBNL. Selain itu adanya tuntutan berkembangan teknologi yang pesat, menjadi fokus kegiatan pengabdian ini untuk memfasilitas pengurus yayasan dapat membuat laporan berbasis digital, sehingga laporan keuangan dapat dibuat dengan mudah.

Laporan keuangan berbasis digital memiliki bentuk penyajian yang bermacam-macam. Penggunaan Microsoft Excel merupakan salah satu bentuk penyajian yang paling sederhana akan tetapi membutuhkan pengetahuan lebih dalam terhadap ilmu akuntansi dalam rangka penyusunan laporan keuangan berbasis digital. Selanjutnya terdapat berbagai macam software untuk membuat laporan keuangan, seperti Jurnal, Zahir Accounting, Accurate Accounting Software, Microsoft Access, Omega Accounting, MYOB Accounting hingga terdapat pada modul Financial pada enterprise resource planning, seperti Oracle Finance dan SAP Finance (Sugiono, 2009; Adenia \& Husaini, 2019). Software tersebut dibuat untuk laporan keuangan dengan standar umum yaitu entitas berorientasi laba 
(EBL), Sedangkan standar laporan keuangan untuk EBNL berbeda. Berdasarkan permasalahan tersebut maka perlu dibuatkan laporan keuangan berbasis digital sesuai kebutuhan entitas. Khususnya untuk EBNL maka perlu dibuatkan software atau aplikasi khusus EBNL.

Interaksi yang terjadi pada organisasi sosial dibutuhkan untuk mempererat jaringan komunikasi dalam mempertahankan eksistensi melalui kerja sama internal dan eksternal kelompok. Bagaimana mereka mendapatkan relawan baru, mempertahankan relawan dalam komunitas. Jaringan sosial dalam mencari donasi maupun cara-cara yang terus dilakukan untuk mencari sumber dana agar kegiatan operasional dalam komunitas sosial dapat terus berjalan. Saat jaringan terbentuk, pemindahan dan penerimaan pesan berpengaruh pada para anggota kelompok. Melalui isu-isu dalam komunitas sosial untuk mempertahankan eksistensinya, maka keberadaan organisasi sosial sendiri diharapkan dapat terus ada untuk membantu mengatasi masalah-masalah sosial yang ada di masyarakat sekitar.

\section{RUMUSAN MASALAH}

Yayasan Radiyatan Mardiyah (YRM) berlokasi di Jalan Prumpung Tengah RT 06/RW 06 No. 18, Kelurahan Cipinang Besar Utara, Jakarta Timur 13410. YRM didirikan pada tanggal 8 September 2019. Tujuan didirikannya YRM adalah mengatasi masalah kemiskinan yang ada di daerah tersebut, karena Prumpung adalah daerah padat dan kumuh. Saat ini pengurus berjumlah 10 orang, dan tenaga relawan pengajar sebanyak 5 orang. Fasilitas yang dimiliki yayasan masih sangat terbatas. Selain memiliki keterbatasan fasilitas, YRM juga memiliki keterbatasan dalam mengelola organisasi sehingga perlu didampingi untuk penguatan organisasi.

Selain itu YRM saat ini mulai menerima donasi dari donator, sehingga YRM perlu transparan dalam melaporkan keuangan atas dana yang diterima dari para donator. Transparansi dan akuntabilitas menjadi suatu hal yang penting bagi yayasan ketika menerima dana dari masyarakat (donator). Namun pengurus saat ini memiliki keterbatasan pemahaman terkait dengan pelaporan keuangan berdasarkan standar akuntansi keuangan yang berlaku.

Adanya keterbatasan pemahaman pengurus YRM terkait dengan manajemen lembaga dan pelaporan keuangan maka YRM ini menjadi objek yang menarik dibantu melalui kegiatan pengabdian kepada masyarakat Universitas Bakrie dengan mengadakan pelatihan dan implementasi pelaporan keuangan berbasis digital untuk mempermudah pengurus yayasan dalam melaporkan keuangan. Berdasarkan hasil survey awal terdapat tiga masalah terbesar di Yayasan Radiyatan Mardiyah Prumpung Tengah Jakarta Timur, yaitu:

1. Permasalahan pada pemahaman wawasan pengelolaan keuangan berbasis digital. 
2. Permasalahan dalam pengelolaan organisasi dari aspek komunikasi internal dan eksternal.

3. Minimnya literasi teknologi untuk program pelaporan keuangan EBNL berbasis digital.

Berdasarkan permasalahan tersebut maka kegiatan pengabdian ini bertujuan memberikan pelatihan terkait dengan komunikasi organisasi dan pelaporan keuangan entitas berorientasi nonlaba (EBNL) kepada YRM berdasarkan Interpretasi Standar Akuntansi Keuangan (ISAK) 35 berbasis digital.

\section{TINJAUAN PUSTAKA}

Laporan Keuangan Entitas Berorientasi Nonlaba (EBNL)

Standar yang mengatur dan memberikan tujuan pelaporan keuangan pada EBNL untuk menyediakan informasi yang relevan kepada pihak yang berkepentingan terutama penyumbang dana, anggota organisasi, kreditur dan pihak lain yang memberikan sumbangsih kepada organisasi nonlaba (Yanuar \& Hanifah, 2020). Pelaporan keuangan EBNL yang mudah dipahami, memiliki relevansi, dan memiliki daya banding yang tinggi.

PSAK adalah suatu pernyataan terkait dengan kerangka prosedur pembuatan laporan keuangan agar terjadi keseragaman dalam penyajian laporan keuangan (Ikatan Akuntansi Indonesia, 2018). PSAK mengacu pada prinsip dan standar akuntansi global yang telah disesuaikan dengan kondisi serta kebutuhan yang ada di Indonesia. Untuk membantu EBNL tersebut maka IAI membuat PSAK 45 untuk mengatur pelaporan keuangan EBNL sebagai bentuk antisipasi perkembangan entitas nonlaba di Indonesia (Ikatan Akuntansi Indonesia, 2018). PSAK 45 dibuat dan disahkan pertama kali oleh DSAK IAI pada tanggal 23 Desember 1987 yang kemudian di revisi dan disahkan kembali pada tanggal 8 April 2011. PSAK 45 Revisi 2011 merupakan standar khusus entitas nonlaba dalam membuat laporan keuangan (Ikatan Akuntansi Indonesia, 2011).

Namun dalam praktiknya menimbulkan ketidakkonsistensian dan serta ketidakjelasan tentang batasan ruang lingkup antara PSAK 1 dan PSAK 45. PSAK 45 dipahami seolah-olah ruang lingkup PSAK 45 berlaku untuk EBNL sedangkan ruang lingkup PSAK 1 dipahami seolah-olah hanya berlaku untuk EBL. Ruang lingkup PSAK 1 secara substansi telah mencakup ruang lingkup penyajian laporan keuangan EBL, namun PSAK 1 tidak menyediakan pedoman bagaimana entitas dengan aktivitas nonlaba menyajikan laporan keuangannya. Sehingga untuk menyelesaikan ketidakjelasan dan permasalahan tersebut maka DSAK IAI mengesahkan Intrepretasi Standar Akuntansi Keuangan (ISAK 35) tentang "Penyajian Laporan Keuangan Entitas Berorientasi Nonlaba" dan mencabut PSAK 45 tentang "Pelaporan Keuangan Entitas Nirlaba" pada tanggal 11 April 2019 yang berlaku efektif untuk periode tahun buku yang dimulai pada 
atau setelah tanggal 1 Januari 2020 (Ikatan Akuntansi Indonesia, 2018).

ISAK 35 yang diterbitkan oleh DSAK IAI menjelaskan bahwa kemampuan EBNL untuk terus dapat memberikan jasa dikomunikasikan melalui laporan keuangan. Terdapat lima laporan keuangan Entitas Nonlaba yang diatur dalam ISAK 35: Laporan Posisi Keuangan (Neraca), Laporan Penghasilan Kompherensif, Laporan Perubahan Aset Neto, Laporan Arus Kas dan Catatan atas Laporan Keuangan.

\section{Laporan Posisi Keuangan (Neraca)}

Laporan posisi keuangan adalah suatu laporan keuangan yang menggambarkan posisi keuangan atau kekayaan suatu perusahaan atau organisasi pada saat tertentu (Ikatan Akuntansi Indonesia, 2018). Tujuan laporan posisi keuangan adalah untuk menyediakan informasi mengenai aset, liabilitas dan aset neto serta informasi mengenai hubungan diantara unsur-unsur tersebut pada waktu tertentu. Informasi dalam laporan posisi keuangan yang digunakan bersama dengan pengungkapan dan informasi laporan keuangan lain untuk membantu pemberi sumber daya yang tidak mengharapkan pembayaran kembali, anggota, kreditur, dan pihak lain untuk menilai kemampuan entitas nonlaba untuk memberikan jasa secara berkelanjutan (Ikatan Akuntansi Indonesia, 2018).

Laporan posisi keuangan menyediakan informasi yang relevan mengenai likuiditas, fleksibilitas keuangan, dan hubungan antara aset dan liabilitas. Aset disusun berdasarkan urutan likuiditasnya yang dikelompokkan dalam aset lancar dan tidak lancar. Liabilitas disusun berdasarkan tanggal jatuh tempo, penyajian liabilitas dikelompokkan ke dalam jangka panjang dan jangka pendek. Aset neto adalah sisa aktiva setelah dikurangi liabilities.

Laporan posisi keuangan menyajikan jumlah masing-masing kelompok aset neto berdasarkan ada atau tidaknya pembatasan oleh penyumbang. Pembatasan sumber daya (with restrictions) adalah pembatasan yang ditetapkan oleh penyumbang agar sumber daya tersebut dipertahankan baik secara permanen maupun temporer dan dibatasi untuk tujuan tertentu oleh penyumbang. Tidak ada pembatasan sumber daya (without restrictions) adalah sumber daya yang penggunaannya tidak dibatasi untuk tujuan tertentu oleh penyumbang.

\section{Laporan Penghasilan Komprehensif}

Laporan penghasilan komprehensif menyajikan hubungan antara penghasilan dan beban dari entitas. Laba sering digunakan sebagai ukuran kinerja atau sebagai dasar untuk pengukuran lain, seperti tingkat pengembalian investasi atau laba per saham. Unsur-unsur laporan keuangan yang secara langsung terkait dengan pengukuran laba adalah penghasilan dan beban. Laporan penghasilan komprhensif minimal mencakup pos-pos diantaranya: beban keuangan, bagian laba atau rugi dari investasi yang menggunakan metode ekuitas, beban pajak dan laba atau rugi neto (Martani, 2012). 
Laporan penghasilan komprehensif EBNL menyajikan jumlah pendapatan dan beban dengan pembatasan dan tanpa pembatasan. Pendapatan dan keuntungan yang menambah aset neto, serta beban dan kerugian yang mengurangi aset neto dikelompokkan menjadi dua bagian yakni tanpa pembatasan dari pemberi sumber daya dan dengan pembatasan dari pemberi sumber daya. Sumbangan yang diterima oleh EBNL disajikan sebagai penambah aset neto bergantung pada ada tidaknya pembatasan. Laporan penghasilan komprehensif juga menyajikan jumlah neto keuntungan dan kerugian yang berasal dari transaksi insidental atau peristiwa lain yang berada di luar pengendalian entitas nonlaba dan manajemen, contohnya keuntungan atau kerugian penjualan tanah dan gedung yang tidak digunakan lagi (Ikatan Akuntansi Indonesia, 2018).

\section{Laporan Perubahan Aset Neto}

Laporan perubahan aset neto adalah laporan keuangan yang mencatat informasi tentang penyebab bertambah dan berkurangnya aset neto selama kurun waktu tertentu (Kasmir, 2013). Laporan perubahan aset neto menunjukkan suatu perubahan dalam aset neto untuk suatu periode termasuk didalamnya pos pendapatan dan beban yang diakui secara langsung dalam aset neto untuk periode tersebut, pengaruh perubahan kebijakan akuntansi dan koreksi kesalahan yang diakui dalam periode tersebut.

\section{Laporan Arus Kas}

Laporan arus kas menyajikan informasi perubahan historis atas kas dan setara kas entitas, yang menunjukkan secara terpisah perubahan yang terjadi selama satu periode dari aktivitas operasi, investasi dan pendanaan. Laporan arus kas melaporkan arus kas selama periode tertentu dan diklasifikasi menurut aktivitas operasi, investasi, dan pendanaan (Ikatan Akuntansi Indonesia, 2018).

Tujuan utama laporan arus kas adalah menyajikan informasi mengenai penerimaan dan pengeluaran kas dalam suatu periode. Arus kas dari aktivitas operasi yaitu menggambarkan arus kas masuk dan arus kas keluar dari aktivitas utama organisasi, merupakan indikator yang menentukan apakah dari operasinya organisasi dapat menghasilkan arus kas yang cukup untuk memelihara kemampuan operasi organisasi tanpa harus mengandalkan pada sumber pendanaan dari luar. Arus kas dari aktivitas investasi yaitu mencerminkan arus kas masuk dan kas keluar sehubungan dengan sumber daya organisasi yang bertujuan untuk menghasilkan pendapatan dan arus kas masa depan. Arus kas pendanaan yaitu menggambarkan arus kas masuk dan kas keluar yang merupakan sumber pendanaan jangka panjang.

\section{Catatan atas Laporan Keuangan}

Catatan atas laporan keuangan berisi ringkasan kebijakan akuntansi yang signifikan mengenai gambaran umum organisasi, ikhtisar, kebijakan akuntansi, serta penjelasan pos-pos 
laporan keuangan dan informasi penting lainnya. Catatan A menguraikan kebijakan pengungkapan yang diwajibkan yang menyebabkan Catatan B wajib disajikan. Catatan C, D dan E menyediakan informasi yang dianjurkan untuk diungkapkan oleh entitas berorientasi nonlaba.

\section{Komunikasi Organisasi}

Lembaga yang bergerak di dalam bidang sosial memanfaatkan tugas dan fungsi divisi komunikasi dalam melakukan kegiatan komunikasi internal dan eksternal perusahaan. Komunikasi internal dan eksternal ini berguna untuk memantau opini publik yang berkembang di dalam dan luar perusahaan yang dapat digunakan sebagai bahan perumusan dan penetapan kebijaksanaan perusahaan dalam meraih citra positif lembaga yang lebih baik lagi.

Sebagai entitas sosial yang mempunyai tanggung jawab terhadap masyarakat memandang perlu adanya strategik komunikasi yang mempunyai tugas pokok melaksanakan, mengkoordinasikan, memantau, dan menilai pelaksanaan kegiatan komunikasi antara pihak manajemen dengan publik internal dan publik eksternal. Kegiatan yang dilakukan memiliki tujuan mengembangkan goodwill dan opini publik yang favourable atau menciptakan kerja sama berdasarkan hubungan yang harmonis dengan berbagai publik, dan kegiatannya dikerahkan ke dalam dan ke luar lembaga.

Argenti (2003), menyebutnya dengan adanya revolusi di dalam organisasi dan adanya turbulance dalam organisasi, akhirnya strategik manajemen menjadi sangat penting. Strategik manajemen dipelajari karena terutama sebagai orang yang bergerak dalam komunikasi maka komunikasi semakin penting bagi para manajer yaitu komunikasi memberikan peluang untuk memberikan kontribusi besar pada perkembangan sosial. Agar tercapai hal tersebut di dalam sosial, maka komunikasi harus menjadi bagian dalam strategik manajemen. Artinya bahwa orang-orang komunikasi harus bisa memberi masukan yang mempunyai nilai dan layak untuk dipertimbangkan di dalam proses strategik manajemen sehingga harus pula memiliki kompetensi dan legitimasi. Karenanya banyak jabatan yang tadinya sektoral seperti corporate communication dianggap sebagai jabatan yang memiliki strategik manajemen.

Strategik manajemen menjadi penting dan sadar atau tidak setiap orang akan terkena dampaknya (internal atau eksternal) karena strategik manajemen melibatkan putusan puncak, strategik manajemen tidak dapat dirumuskan tanpa adanya keputusan dari puncak, tanpa keterlibatan, tanpa komitmen dari pimpinan puncak (Koteen, 1991). Strategik manajemen selalu melibatkan sumber daya yang besar dari organisasi.

Fungsi manajemen adalah mendukung pembinaan dan pemeliharaan jalur bersama antara organisasi dengan publiknya mengenai komunikasi, pengertian, penerimaan, dan kerja sama; melibatkan manajemen dalam permasalahan atau persoalan; membantu 
manajemen menjadi tahu dan tanggap terhadap opini publik; menetapkan dan menekankan tanggung jawab manajemen untuk melayani kepentingan publik; mendukung manajemen dalam mengikuti dan memanfaatkan perubahan secara efektif. Sehingga manajemen dapat bertindak sebagai sistem peringatan dini dalam membantu mengantisipasi kecenderungan dan menggunakan penelitian serta teknik komunikasi yang sehat dan etis sebagai sarana utama pengumpulan sumber data untuk dijadikan sebagai bahan perumusan kebijakan yayasan yang tepat.

\section{METODOLOGI KEGIATAN}

Metode pelaksanaan kegiatan PkM dilaksanakan tiga tahapan. Tahap pertama adalah pelatihan, pembekalan keterampilan, dan pemahaman komunikasi organisasi dan pelaporan keuangan. Tahap kedua adalah sosialisasi aplikasi digital laporan keuangan ISAK 35 sekaligus praktik untuk pembuatan pelaporan keuangan. Tahap Ketiga adalah tahapan lanjutan dari kegiatan ini dalam bentuk monitoring dan evaluasi (monev) melalui pendampingan secara bertahap.

Tahap pertama adalah pelatihan untuk pembinaan keorganisasian yang dirancang untuk memperkuat interaksi internal organisasi sosial, seperti: pelatihan komunikasi organisasi, kepemimpinan, pengelolaan keuangan, dan literasi teknologi. Pelatihan pemahaman, pembuatan dan implementasi laporan keuangan
EBNL sesuai standar akuntansi yang berlaku (ISAK 35). Pelatihan dilaksanakan dengan mengadakan workshop mengaplikasikan pengetahuan yang sudah didapat dalam bentuk penyusunan laporan keuangan dengan aplikasi digital.

Tahap kedua adalah sosialisasi aplikasi keuangan berbasis digital termasuk pengenalan web organisasi serta evaluasi hasil dari pelatihan yang diberikan melalui tahap pertama. Sosialisasi dalam bentuk penjelasan web Yayasan, serta pengoperasian laporan keuangan berbasis digital berdasarkan ISAK 35. Selanjutnya dilakukan evaluasi dengan membandingkan pemahaman peserta pelatihan sebelum pelatihan dan setelah pelatihan terkait dengan penguatan organisasi dan pelaporan keuangan. Selain itu evaluasi dilakukan dengan menguji kemampuan peserta dalam mengoperasikan teknologi dalam pelaporan keuangan.

Tahap ketiga yaitu monitoring dan evaluasi setelah kegiatan melalui pemberian pendampingan dalam penguatan organisasi dan literasi teknologi dalam pembinaan di Yayasan Radiyatan Mardiyah Prumpung Tengah Jakarta Timur. Monitoring dan pendampingaan ini untuk memastikan pelatihan memberikan manfaat bagi peserta, selain itu peserta mampu menerapkan atau mempraktikkan apa yang telah diberikan melalui pelatihan untuk mengelola organisasi dan pelaporan keuangan. 


\section{HASIL DAN PEMBAHASAN}

Pelaksanaan kegiatan PkM dilakukan dalam dua tahap. Tahap pertama adalah pelatihan komunikasi organisasi dan laporan keuangan keuangan berbasis web berdasarkan ISAK 35. Tahap kedua adalah sosialisasi laporan keuangan berbasis web (digital) berdasarkan ISAK 35.

Tahap pertama pelaksanaan kegiatan adalah pelatihan yang dilaksanakan pada hari Sabtu tanggal 3 April 2021 pukul 13.00 s.d. 16.00. Kegiatan PkM ini dilaksanakan dalam bentuk pelatihan dengan judul "Pelatihan Komunikasi Organisasi dan Laporan Keuangan Berdasarkan ISAK 35 Berbasis Digital di Yayasan Radiyatan Mardiyah Prumpung Jakarta Timur".

Pelatihan dilaksanakan secara online menggunakan aplikasi Cisco Webex. Kegiatan pelatihan ini melibatkan mahasiswa program studi Akuntansi Universitas Bakrie. Peserta pelatihan adalah pengurus Yayasan Radiyatan Mardiyah sebanyak delapan (8) orang. Metode kegiatan pelatihan dibagi dalam 3 sesi yaitu sesi pertama tes awal (pre-test) untuk mengetahui pemahaman peserta pelatihan terkait komunikasi organisasi dan laporan keuangan, sesi kedua adalah pemaparanan materi oleh narasumber dan sesi tiga adalah diskusi dan tanya jawab dengan narasumber dan dibantu oleh mahasiswa.

Peserta pelatihan lebih banyak wanita $(62,5 \%)$ dari pada pria $(37,5 \%)$. Pendidikan peserta peserta rata-rata adalah sarjana S1 (50\%), sedangkan S3 (12,5\%), dan SMA (37,5\%).
Berdasarkan hasil survey menyimpulkan bahwa peserta pelatihan lebih banyak yang belum pernah pelatihan mengikuti pelatihan akuntansi (75\%), meskipun peserta sudah pernah membuat laporan keuangan sederhana $(87,5 \%)$ yang sifatnya hanya pencatatan pemasukan (kas masuk) dan pengeluaran (kas keluar). Selain itu pemahaman konsep terkait dengan komunikasi organisasi masih terbatas (75\%).

Sesi kedua dilanjutkan dengan pemaparan materi oleh narasumber. Materi pertama terkait dengan komunikasi organisasi yang disampaikan oleh Ibu Dr. Tuti Widiastuti, dosen Program Studi Ilmu Komunikasi. Materi komunikasi organisasi yang dijelaskan adalah konsep utama komunikasi dan organisasi, tiga model komunikasi, komunikasi organisasi, dan fungsi komunikasi organisasi. Selanjutnya dilanjutkan dengan pemaparan materi laporan keuangan oleh Ibu Dr. Jurica Lucyanda, dosen Program Studi Akuntansi. Materi laporan keuangan yang dijelaskan adalah siklus akuntansi dan laporan keuangan berdasarkan ISAK 35.

Terakhir pemaparan materi website Yayasan dan rencana aplikasi laporan keuangan digital oleh Bapak Berkah Iman Santoso, S.T., M.T.I, dosen Program Studi Informatika. Saat pelatihan ini sistem informasi akuntansi digital berbasis ISAK 35 sedang dibuat/didesain, namun website Yayasan sudah dibuat, di mana website Yayasan Radiyatan Mardiyah baru berisi profil dan kegiatan-kegiatan sosial anggota Yayasan. Website Yayasan Radiyatan Mardiyah sudah 
dapat diakses

melalui

laman http://www.yayasanradiayatanmardiyah.org.

Pada website tersebut memuat informasi profil Yayasan Radiyatan Mardiyah, dokumentasi kegiatan dalam bentuk foto-foto kegiatan pada laman http://www.yayasanradiyatanmardiyah. org/activities/Activities.html dan link beberapa video kegiatan ke kanal Youtube pada laman http://www.yayasanradiyatanmardiyah.org/vid eos/Home.html serta link untuk Login pada aplikasi pelaporan keuangan berbasis web untuk Yayasan berbasis ISAK 35 pada laman http://www.yayasanradiyatanmardiyah.org/app syrm/index.html.

Sesi ketiga adalah diskusi dan tanya jawab peserta pelatihan, sesi ini dipandu oleh mahasiswa akuntansi Universitas Bakrie. Berdasarkan hasil tes awal (pre-test) yang dilakukan melalui Google Form maka dapat disimpulkan bahwa secara umum peserta pelatihan paham laporan keuangan sederhana namun masih belum paham terkait dengan pelaporan keuangan khususnya laporan keuangan berbasis ISAK 35. Sesi ini lebih dijelaskan secara detail format pelaporan keuangan berdasarkan ISAK 35. Keterbatasan pemahaman pengurus Yayasan terkait laporan keuangan ISAK 35 disebabkan karena latar belakang pendidikan bukan dari akuntansi.

Untuk memastikan adanya penambahan pemahaman pengurus Yayasan terkait laporan keuangan ISAK 35 maka diadakan kegiatan lanjutan yaitu sosialisasi aplikasi laporan keuangan Yayasan berbasis digital. Sosialisasi ini bertujuan menjelaskan tahapan yang harus dilakukan oleh operator (bagian akuntansi) memasukkan transaksi-transaksi keuangan dalam sistem laporan keuangan yang telah dibuat. Dimulai dari pencatatan transaksi rutin dan akhirnya menjadi laporan keuangan Yayasan. Foto kegiatan pelatihan yang ditunjukkan pada Gambar 1.

Baknite

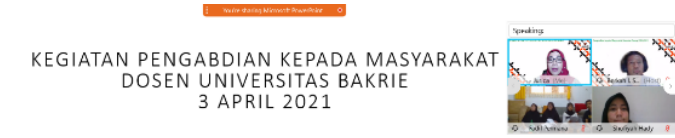

PELATIHAN KOMUNIKASI ORGANISASI DAN

LAPORAN KEUANGAN BERDASARKAN ISAK 35 BERBASIS DIGITAL DI YAYASAN RADIYATAN MARDIYAH PRUMPUNG JAKARTA TIMUR

$$
\begin{aligned}
& \text { TIM } \\
& \text { JURICA LUCYANDA } \\
& \text { TUTI WIDIASTUTI } \\
& \text { BERKAH IMAN SANTOSO } \\
& \text { SHOFIYAH HADI } \\
& \text { FADIL PERMANA }
\end{aligned}
$$

Gambar 1. Foto Kegiatan "Pelatihan Komunikasi Organisasi dan Laporan Keuangan Berdasarkan ISAK 35 Berbasis Digital di Yayasan Radiyatan Mardiyah Prumpung"

Tahap kedua pelaksanaan kegiatan pengabdian kepada masyarakat adalah sosialisasi laporan keuangan berbasis web berdasarkan ISAK 35. Kegiatan ini dilaksanakan pada hari Sabtu, tanggal 31 Juli 2021 pukul 19.00 s.d. 22.00. Kegiatan PkM ini dilaksanakan dalam bentuk sosialisasi kepada pengurus Yayasan dengan judul "Sosialisasi Laporan Keuangan Berdasarkan ISAK 35 Berbasis Digital Yayasan Radiyatan Mardiyah Prumpung Jakarta Timur". Pelatihan dilaksanakan secara online menggunakan aplikasi Zoom Meeting.

Kegiatan sosialisasi ini melibatkan mahasiswa program studi Akuntansi Universitas Bakrie. Peserta pelatihan adalah pengurus 
Yayasan Radiyatan Mardiyah sebanyak empat (4) orang yang terdiri dari ketua Yayasan, bagian keuangan Yayasan, bendahara Yayasan, dan bagian akuntansi. Metode kegiatan sosialisasi dibagi dalam dua sesi yaitu sesi pertama pemaparan materi oleh nara sumber yaitu Bapak Berkah Iman Santoso dari Program Studi Teknik Informatika dan sesi kedua adalah diskusi dan tanya jawab dengan narasumber dan tim dan dibantu oleh mahasiswa.

Tahap kedua ini bertujuan menjelaskan lebih detail laporan keuangan berdasarkan ISAK 35 yang berbasis dgital. Dengan laporan keuangan yang berbasis digital ini mempermudah pengurus dalam membuat laporan keuangan Yayasan. Secara umum pengurus Yayasan antusias mengikuti sosialisasi ini karena laporan keuangan berbasis web ini akan membantu YRM dalam membuat pelaporan keuangan khususnya laporan keuangan berbasis ISAK 35. Untuk memastikan keberhasilan dari sosialisasi ini akan diadakan kegiatan lanjutan dari pengabdian kepada masyarakat ini yaitu pendampingan melalui monitoring dan evaluasi (monev). Foto kegiatan pelatihan yang ditunjukkan pada Gambar 2.

Akuntansi adalah informasi yang menyediakan laporan untuk para pemangku kepentingan mengenai aktivitas ekonomi dan kondisi perusahaan (Reeve, Warren, \& Duchac, 2013). Secara umum hasil dari kegiatan atau aktivitas akuntansi tersebut adalah laporan keuangan.

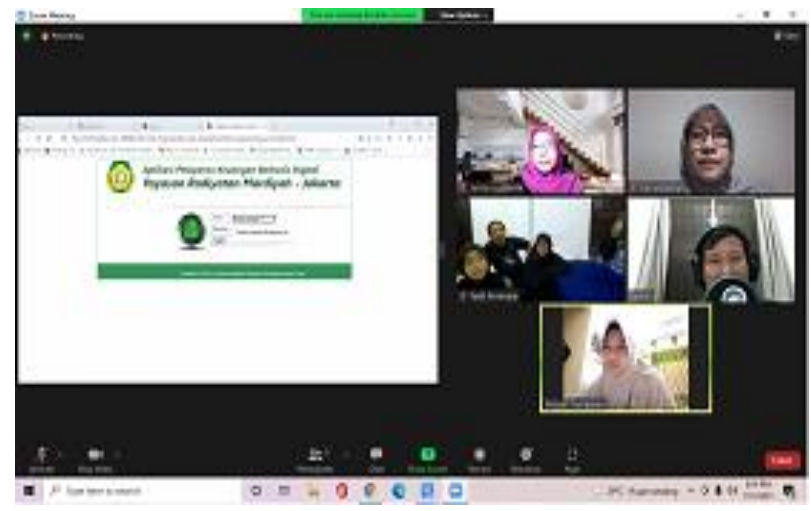

Gambar 2. Foto Kegiatan "Sosialisasi Laporan Keuangan Berdasarkan ISAK 35 Berbasis Digital di Yayasan Radiyatan Mardiyah Prumpung"

Menurut IAI (2018) dalam Pernyataan Standar Akuntansi Keuangan (PSAK) No. 1, laporan keuangan adalah catatan informasi keuangan suatu perusahaan pada suatu periode akuntansi yang dapat digunakan untuk menggambarkan kinerja perusahaan tersebut. Kasmir (2013), menjelaskan bahwa laporan keuangan bertujuan untuk memberikan informasi keuangan suatu perusahaan kepada pihak dalam dan luar perusahaan yang memiliki kepentingan terhadap perusahaan.

\section{KESIMPULAN}

Tujuan utama kegiatan pengabdian masyarakat ini adalah penguatan organisasi dan akuntabilitas lembaga melalui kegiatan penjelasan dan pelatihan terkait dengan komunikasi internal dan eksternal serta pelaporan keuangan entitas berorientasi nonlaba (Yayasan) berdasarkan ISAK 35 berbasis digital. Tujuan khusus kegiatan pengabdian kepada masyarakat adalah memberikan pelatihan komunikasi internal dan eksternal dan implementasi pelaporan keuangan berbasis 
digital berdasarkan ISAK 35. Dengan adanya pelatihan ini peserta pelatihan memahami bagaimana pentingnya pelaporan keuangan entitas khususnya entitas berorientasi nonlaba, mampu dan terampil membuat laporan keuangan sebagai pertanggungjawaban keuangan entitas. mampu dan terampil menggunakan teknologi sebagai alat komunikasi laporan keuangan (aplikasi laporan keuangan berbasis digital), dan mampu mengatasi permasalahan dalam mengelola organisasi dari aspek komunikasi internal dan eksternal.

Pelatihan dilakukan dalam bentuk pemaparan materi oleh narasumber. Materi pertama terkait dengan komunikasi organisasi yang disampaikan oleh Ibu Dr. Tuti Widiastuti, dosen Program Studi IImu Komunikasi. Materi komunikasi organisasi yang dijelaskan adalah konsep utama komunikasi dan organisasi, tiga model komunikasi, komunikasi organisasi, dan fungsi komunikasi organisasi. Materi ini adalah untuk penguatan organisasi, menjelaskan bagaimana peran komunikasi internal dan eksternal untuk pengembangan organisasi. Selanjutnya dilanjutkan dengan pemaparan materi laporan keuangan oleh Ibu Dr. Jurica Lucyanda, dosen Program Studi Akuntansi. Materi laporan keuangan yang dijelaskan adalah siklus akuntansi dan laporan keuangan berdasarkan ISAK 35. Materi ini adalah sebagai bentuk transparansi dan akuntabilitas Yayasan untuk mempertanggungjawabkan dana yang diterima dari pihak eksternal. Terakhir pemaparan materi website Yayasan dan rencana aplikasi laporan keuangan digital oleh Bapak Berkah Iman Santoso, S.T., M.T.I, dosen Program Studi Informatika. Materi ini menjelaskan sistem informasi akuntansi berbasis digital atau menggunakan software laporan keuangan untuk membantu dalam mempermudah pembuatan laporan keuangan Yayasan.

Untuk memastikan keberhasilan dari sosialisasi ini akan diadakan kegiatan lanjutan dari pengabdian kepada masyarakat ini yaitu pendampingan melalui monitoring dan evaluasi (monev). Pendampingan ini perlu dilakukan untuk memastikan bahwa pengurus Yayasan mampu mengimplementasikan pelaporan keuangan menggunakan aplikasi yang telah dibuat untuk YRM.

\section{UCAPAN TERIMA KASIH}

Terima kasih kepada Lembaga Pengabdian kepada Masyarakat (LPkM) Universitas Bakrie yang telah mendanai dan memfasilitasi kegiatan pengabdian kepada masyarakat. Terima kasih kepada Yayasan Radiyatan Mardiyah yang telah menjadi mitra kegiatan pengabdian kepada masyarakat.

\section{DAFTAR PUSTAKA}

Adenia, Q., S. \& Husaini, A. (2019). Analisis Penerapan Digitalisasi Laporan Keuangan pada Usaha Kecil. Jurnal Administrasi sosial (JAB), 72(2), 110-119. 
Argenti, P., A. (2003). Corporate Communication. Reeve, J. M., Warren, C. S., dan Duchac, J. E. New York: McGrawHill/Irvin. (2013). Principles of Accounting. 24th Edition.

Ikatan Akuntansi Indonesia. (2011). PSAK No. 45 Singapura: Cengage Learning Asia Pte Ltd.

Revisi 2011. Dewan Standar Akuntansi Sugiono, A. (2009). Akuntansi dan Pelaporan Keuangan. Jakarta: Salemba Empat. Keuangan untuk Sosial Skala Kecil dan Ikatan Akuntansi Indonesia. (2018). ISAK 35. Menengah. Jakarta: Grasindo.

Dewan Standar Akuntansi Keuangan. Jakarta: Wahyuningsih, Karamoy, H., \& Afandy, D. (2018). Salemba Empat. Analisis Pelaporan Keuangan di Yayasan AsKasmir. (2013). Bank dan Lembaga Keuangan Salam Manado (Berdasarkan PSAK 45 dan Lainnya, Edisi Revisi, Cetakan 12. Jakarta: PSAK 109). Jurnal Riset Akuntansi Going Rajawali Pers. Concern, 13(2), 512-528.

Koteen, J. (1991). Strategic Management in Yanuar, F. A.R., \& Hanifah, W.S. (2020). Telaah Public and Nonprofit Organizations. New Penerapan PSAK 45 dan PSAK 109 dalam York: Praeger Publishers. Rekontruksi Akuntansi Pelaporan Keuangan Martani, D. (2012). Akuntansi Keuangan Masjid: Sebuah Studi Literatur. Jurnal Menengah Berbasis PSAK. Jakarta: Salemba Akuntansi Syariah, 4(1), 45-55.

Empat. 